KS. DAWID PIETRAS

Wydział Prawa Kanonicznego

Uniwersytetu Kardynała Stefana Wyszyńskiego w Warszawie

\title{
NADZWYCZAJNA FORMA RYTU RZYMSKIEGO
}

Treść: Wstęp. - 1. Pierwsze zezwolenia na stosowanie Mszału z 1962 r. po II Soborze Watykańskim. - 2. Okoliczności i cele wydania Motu Proprio Summorum Pontificum w 2007 r. - 3. Dwie formy rytu rzymskiego i kwestia zakazu Mszału Jana XXIII. - 4. Podstawowe regulacje prawne użycia nadzwyczajnej formy rytu rzymskiego. - 5. Papieska Komisja Ecclesia Dei. - 6. Wspólnoty w pełnej jedności z Kościołem katolickim. - 7. Wspólnoty bez pełnej jedności z Kościołem katolickim. - Zakończenie.

\section{Wstęp}

Dnia 14 września 2007 r. w życie Kościoła wszedł dokument Benedykta XVI, którym było Motu Proprio Summorum Pontificum ${ }^{1}$. Tym dekretem, na mocy władzy ustawodawczej Biskupa Rzymskiego, papież wprowadził w Kościele łacińskim nowe normy korzystania z Mszału Jana XXIII z 1962 r. oraz sprawowania innych obrzędów według formy liturgii rzymskiej sprzed II Soboru Watykańskiego (1962-1965). Benedykt XVI wydał także List Apostolski do Biskupów z okazji publikacji Motu Proprio Summorum Pontificum². W 2011 r.

\footnotetext{
${ }^{1}$ Por. Benedictus XVI, Littera Apostolica Motu Proprio data de usu extraordinario antiquae formae Ritus Romani Summorum Pontificum (7 VII 2007), AAS 99(2007), pp. 777-781; tekst polski: Benedy kt XVI, List Apostolski Motu Proprio Summorum Pontificum, Anamnesis 13(2007) nr 4, s. 9-12 [dalej: SP].

${ }^{2}$ Por. Tenże, Epistula ad Episcopos Catholicae Ecclesiae Ritus Romani (7 VII 2007), AAS 99(2007), pp. 795-799; tekst polski: BENEDYKT XVI, List do biskupów z okazji
} 
natomiast Stolica Apostolska wydała Instrukcję Universae Ecclesiae ${ }^{3}$, która uszczegóławia sposób realizacji postanowień papieskiego Motu Proprio.

W niniejszym artykule zostaną przedstawione główne racje wprowadzenia tych dokumentów i naświetlona zostanie sytuacja tej liturgii w Kościele po II Soborze Watykańskim. Ukazane zostaną aktualne normy, przez które prawodawca reguluje sprawowanie liturgii w nadzwyczajnej formie rytu rzymskiego. Przedstawiona będzie również krótka charakterystyka i różnorodność podstawowych struktur kościelnych, w których celebrowana jest ta forma liturgii.

Zaznaczyć również należy, iż temat niniejszego artykułu jest niemal zupełnie nieopracowany w kanonistyce polskiej. Szerzej natomiast został on podjęty w kanonistyce zagranicznej ${ }^{4}$.

\section{Pierwsze zezwolenia na stosowanie Mszału z 1962 r. po II Soborze Watykańskim}

Normy wprowadzone w Motu Proprio Summorum Pontificum z 2007 r. zastąpiły wcześniejsze regulacje, wyrażone w Dekrecie Quatuor abhinc annos ${ }^{5}$ Świętej Kongregacji Kultu Bożego z 1984 r.

publikacji Motu Proprio „Summorum Pontificum”, Anamnesis 13(2007) nr 4, s. 13-16 [dalej: LdB].

${ }^{3}$ Por. Pontificia Commissio Ecclesia DeI, Instructio Universae Ecclesiae (30 IV 2011), AAS 103(2011), pp. 413-420; tekst polski: PAPIESKA KomisJa ECCLESIA DEI, Instrukcja Universae Ecclesiae, Wiadomości Urzędowe Diecezji Opolskiej 10-11(2011), s. 428-436 [dalej: UE].

${ }^{4}$ Do kanonistów, którzy podjęli ten temat należy m.in. Chad J. Glendinning, który w 2010 r. obronił pracę doktorską w Ottawie na Uniwersytecie Świętego Pawła pt. Summorum Pontificum and the use of the extraordinary form of the roman rite: A canonical analysis in light of the current liturgical law. Napisał również szereg artykułów w tym zakresie np. The Significance of the Liturgical Reforms Prior to the Second Vatican Council in Light of "Summorum Pontificum”, Studia Canonica 44(2010) nr 2, pp. 293-342. Kolejnym kanonistą, który podjął tę tematykę jest G.P. Weishaupt. Napisał np. „Universae Ecclesiae”: text and commentary, Studia Canonica 45(2011), s. 355-409.

${ }^{5}$ Por. Sacra Congregatio pro Cultu Divino, Epistula de usu Missalis Romani iuxta editionem typicam anni MCMLXII Quatuor abhinc annos (3 X 1984), AAS 
oraz Motu Proprio Jana Pawła II Ecclesia Dei adflicta ${ }^{6}$ z 1988 r. (SP 1). Jednak już od 1969 r. Stolica Apostolska upoważniła ordynariuszy do udzielania zezwoleń na korzystanie z Mszału z 1962 r. dla kapłanów starszych i chorych, którzy mieli problemy z dostosowaniem się do reformowanej liturgii ${ }^{7}$. Podobnie w 1971 r. papież Paweł VI udzielił indultu dla Anglii i Walii. Według niego ordynariusze mogli udzielać kapłanom zezwoleń na celebrację według Mszału z 1962 r. ${ }^{8}$ Zaznaczyć jednak należy, iż przy obydwu ww. zezwoleniach należało uwzględnić zmiany w liturgii Mszy wprowadzone przez Instrukcję Inter oecumenici $\mathrm{z} 1965$ r. ${ }^{9}$ oraz Tres abhinc annos z 1967 r. ${ }^{10}$

76(1984), pp. 1088-1089; tekst polski: Święta Kongregacja Kultu Bożego, List w sprawie używania Mszału Rzymskiego wedtug wydania typicznego $z$ r. 1962, http:// trydent.poznan.pl/dokument_quattuor_abhinc_annos.php [dostęp: 8 XII 2017].

${ }^{6}$ Por. Joannes Paulus II, Littera Apostolica Motu Proprio data quibus Commissio quaedam ad plenam ecclesialem communionem Fraternitatis sacerdotalis a sancto Pio X sodalium vel eidem coniunctorum expediendam instituitur Ecclesia Dei adflicta (2 VII 1988), AAS 80(1988), pp. 1495-1498; tekst polski: JAN PAWE€ II, List Apostolski Motu Proprio Ecclesia Dei w sprawie Arcybiskupa Marcela Lefebvre, w: Listy pasterskie Ojca Świętego Jana Pawła II, Kraków 1997, s. 416-420 [dalej: EDa].

${ }^{7}$ Por. Sacra Congregatio pro Cultu Divino, Instructio de Constitutione Apostolica "Missale Romanum” gradatim ad effectum deducenda Constitutione Apostolica (20 X 1969), AAS 61(1969), pp. 749-753; tekst polski: ŚWIĘTA KongreGACJA Kultu BożEgo, Instrukcja dotyczaca stopniowego wprowadzania w życie Konstytucji Apostolskiej Missale Romanum, Posoborowe Prawodawstwo Kościelne, t. II, z. 3, Warszawa 1970, s. 238-248.

${ }^{8}$ Por. Sacred Congregation for Divine Worship, Indult for England and Wales (5 XI 1971), Prot. N. 1897/71, https://lms.org.uk/heenan-indult [dostęp: 10 X 2017].

${ }^{9}$ Por. Sacra Congregatio Rituum, Instructio ad exsecutionem Constitutionis de Sacra Liturgia recte ordinandam Inter oecumenici (26 IX 1964), AAS 56(1964), pp. 877-900; tekst polski: ŚWIĘTA KONGREGACJA OBRZĘDÓw, Instrukcja o należytym wykonaniu Konstytucji o świętej Liturgii, w: Posoborowe Prawodawstwo Kościelne, t. 2, Warszawa 1968, s. 169-222.

${ }^{10}$ Por. Tenże, Instructio altera ad exsecutionem Constitutionis de sacra Liturgia recte ordinandam Tres abhinc annos (4 V 1967), AAS 59(1967), pp. 442-446; tekst polski: ŚwiĘTa Kongregacja ObrzęDów, Druga Instrukcja wykonawcza do Konstytucji o świętej Liturgii, w: Posoborowe Prawodawstwo Kościelne, t. 2, Warszawa 1968, s. 223-237. 
Dopiero we wspomnianym Dekrecie Quatuor abhinc annos, udzielono zezwolenia na korzystanie z Mszału Jana XXIII z 1962 r. bez uwzględniania późniejszych zmian. Takiego zezwolenia mieli udzielać biskupi diecezjalni pod ściśle określonymi warunkami ${ }^{11}$. Następnie Jan Paweł II w Motu Proprio Ecclesia Dei adflicta w 1988 r. przynaglił biskupów, by hojnie korzystali z udzielonej im władzy wydawania zezwoleń na stosowanie wcześniejszego Mszału (EDa 5c). Owe Motu Proprio zostało wydane dwa dni po tym, jak abp Marcel Lefebvre udzielił sakry biskupiej czterem prezbiterom Bractwa Kapłańskiego Św. Piusa X bez mandatu Stolicy Apostolskiej, za co została zadeklarowana kara ekskomuniki latae sententiae (EDa 3). Nad realizacją tego Motu Proprio czuwać miała powołana wtedy Papieska Komisja Ecclesia Dei (EDa 6).

\section{Okoliczności i cele wydania Motu Proprio Summorum Pontificum w 2007 r.}

W Liście Apostolskim dołączonym do Motu Proprio Summorum Pontificum Benedykt XVI stwierdził, że dotychczasowe regulacje celebracji Mszy przedsoborowej były niewystarczające. Wzrastała też ilość próśb wiernych o szerszą możliwość sprawowania tej liturgii. Dlatego Benedykt XVI ostatecznie zdecydował się zweryfikować normy celebracji tej liturgii w Kościele łacińskim. Po konsultacji z kardynałami na konsystorzu w dn. 23 marca 2006 r. podjął decyzję rozszerzenia dostępu do liturgii sprzed II Soboru Watykańskiego. Dn. 7 lipca 2007 r. wydał więc dekret generalny w formie Motu Proprio, zatytułowany jako Summorum Pontificum od jego pierwszych łacińskich słów (SP 12). W tym samym dniu papież opublikował również List do Biskupów, w którym udzielił dodatkowych wyjaśnień nt. stosowności i potrzeby wprowadzenia tego Motu Proprio (UE 7).

\footnotetext{
${ }^{11}$ Biskupi mieli obowiązek informować Stolicę Apostolską o udzielanych zezwoleniach oraz składać sprawozdanie z jego realizacji. Celebracja - poza wyjątkami miała się odbywać w kościele lub kaplicy poza parafią w dni wyznaczone przez biskupa.
} 
Pierwszą publiczną wypowiedzią Benedykta XVI nt. wprowadzenia nadzwyczajnej formy rytu rzymskiego po opublikowaniu Motu Proprio Summorum Pontificum była wypowiedź w trakcie konferencji prasowej w 2008 r. podczas lotu na pielgrzymkę do Paryża. Papież zapewniał, że Motu Proprio jest wyrazem tolerancji i miłości pasterskiej wobec wiernych przywiązanych do tej liturgii. Nie jest to sprzeczne z intencją ojców II Soboru Watykańskiego, którzy również sprawowali tę liturgię, jednocześnie mając w planie jej reformę. Benedykt XVI wskazał także na żywy rozwój liturgii, która zachowuje swoją tożsamość w tym procesie rozwoju ${ }^{12}$.

Następnie 30 kwietnia 2011 r. papież zatwierdził Instrukcję Universae Ecclesiae do Motu Proprio Summorum Pontificum, wydaną przez Papieską Komisję Ecclesia Dei. Jest ona rezultatem sprawozdań, jakie mieli złożyć biskupi po trzech latach realizacji papieskiego Motu Proprio w ich diecezjach (UE 12) ${ }^{13}$. Jej celem jest również przypomnienie o zasadach wprowadzonych w Motu Proprio Summorum Pontificum

\footnotetext{
${ }^{12}$ Por. Entretien du Pape Benoît XVI accordé aux juornalistes au cours du vol vers la France (12 IX 2008), http://w2.vatican.va/content/benedict-xvi/fr/speeches/2008/ september/documents/fben-xvi_spe_20080912_francia-interview.html [dostęp: 17 XII 2017]. „C'est une peur infondée parce que ce Motu proprio est simplement un acte de tolérance, dans un but pastoral pour des personnes qui ont été formées dans cette liturgie, l'aiment, la connaissent, et veulent vivre avec cette liturgie. C'est un petit groupe parce que cela suppose une formation en latin, une formation dans une culture certaine. Mais pour ces personnes avoir l'amour et la tolérance de permettre de vivre avec cette liturgie cela me semble une exigence normale de la foi et de la pastorale d'un évêque de notre Eglise. Il n'y a aucune opposition entre la liturgie renouvelée par le Concile Vatican II et cette liturgie. Chaque jour (du Concile, ndlr), les pères conciliaires ont célébré la messe selon l'ancien rite et, en même temps, ils ont conçu un développement naturel pour la liturgie dans tout ce siècle car la liturgie est une réalité vivante qui se développe et conserve dans son développement son identité".

${ }^{13}$ Por. Pontificia Commissione EcClesia Dei, Nota redazionale sull'istruzione Universae Ecclesiae, http://www.vatican.va/roman_curia/pontifical_commissions/ ecclsdei/documents/rc_com_ecclsdei_doc_20110513_nota-universae-ecclesiae_ it.html [dostęp: 10 X 2017]; tekst polski: Papieska Komisja Ecclesia DeI, Nota redakcyjna, Wiadomości Urzędowe Diecezji Opolskiej 10-11(2011), s. 437. „Tenendo conto delle osservazioni dei Pastori della Chiesa di tutto il mondo, e avendo raccolto
} 
(UE 5). W tejże Instrukcji doprecyzowano, że Motu Proprio Summorum Pontificum stanowi istotny wyraz magisterium papieża i jego posługi (munus), której celem jest regulowanie świętej liturgii Kościoła i kierowanie nią. Był więc to przejaw troski Zastępcy Chrystusa i Pasterza Kościoła powszechnego o liturgię (UE 8, kan. 331, $838 \$ 1-2$ $\left.\mathrm{KPK}^{14}\right)$.

W instrukcji Universae Ecclesiae podaje trzy przyczyny wprowadzenia papieskiego Motu Proprio: „a) ofiarowanie wszystkim wiernym liturgii rzymskiej w usus antiquior, jako skarbu do najstaranniejszego zachowania; b) zagwarantowanie i realne zapewnienie używania nadzwyczajnej formy wszystkim tym, którzy tego pragną - w takim rozumieniu, że używanie liturgii rzymskiej obowiązującej w 1962 jest prawem danym dla dobra wiernych, a więc ma być interpretowane w sensie przychylnym dla wiernych, którzy są jego głównymi adresatami; c) sprzyjać pojednaniu wewnątrz Kościoła" (UE 8) ${ }^{15}$. Dla realizacji ww. celów zobligowano biskupów diecezjalnych do podjęcia realizacji papieskiego Motu Proprio: „Jest zadaniem biskupa diecezjalnego podjęcie wszelkich koniecznych środków dla zapewnienia należytego szacunku dla nadzwyczajnej formy Rytu Rzymskiego, zgodnie z Motu Proprio Summorum Pontificum" (UE 14) ${ }^{16}$.

Do wytycznych opublikowanych w Motu Proprio Sumorum Pontificum ustosunkowywały się niektóre Konferencje Biskupów, wydając

domande di chiarificazione e richieste di indicazioni specifiche, viene ora pubblicata la seguente Istruzione dall'incipit latino: Universae Ecclesiae".

${ }^{14}$ Por. Codex Iuris Canonici, Auctoritate Ioannis Pauli PP. II promulgatus (25 I 1983), AAS 75(1983), part. II, pp. 1-317; tekst polski: Kodeks Prawa Kanonicznego. Przekład polski zatwierdzony przez Konferencję Episkopatu, Poznań 1984 [dalej: KPK].

${ }^{15}$ „Ipsae Litterae intendunt: a) Liturgiam Romanam in Antiquiore Usu, prout pretiosum thesaurum servandum, omnibus largiri fidelibus; b) Usum eiusdem Liturgiae iis re vera certum facere, qui id petunt, considerando ipsum Usum Liturgiae Romanae anno 1962 vigentem esse facultatem ad bonum fidelium datam, ac proinde in favorem fidelium benigne esse interpretandam, quibus praecipue destinatur; c) Reconciliationi in sinu Ecclesiae favere".

${ }^{16}$ „E compito del Vescovo diocesano adottare le misure necessarie per garantire il rispetto della forma extraordinaria del Rito Romano, a norma del Motu Proprio Summorum Pontificum". 
stosowne oświadczenia ${ }^{17}$. Konferencje Episkopatu Polski ${ }^{18}$, Niemiec $^{19}$ i Szwajcarii ${ }^{20}$ wydały również wytyczne dla swoich Kościołów partykularnych. W swoim wyjaśnieniu kard. Karl Lehmann w imieniu Konferencji Episkopatu Niemiec tak komentował cele wprowadzenia papieskiego Motu Proprio: „Ojciec Święty reaguje w ten sposób na odpowiednie stałe prośby i pragnie wielkodusznie wyjść naprzeciw tym, którzy czują się przywiązani do starej formy liturgii mszalnej. Tą inicjatywą papież Benedykt pragnie przyczynić się także do pojednania w Kościele. (...) Biskupi niemieccy wyraźnie popierają tę sprawę i mają nadzieję, że nowe Motu Proprio i jego prawne postanowienia pomogą przywrócić pełną jedność z tymi, którzy z powodu liturgicznych przemian po II Soborze Watykańskim oddzielili się od wspólnoty z Papieżem. (...) Papieżowi chodzi więc o to, by poszczególnym księżom i trwale istniejącym grupom, które czują się związane ze starszą postacią liturgii, wielkodusznie rozszerzyć do niej przystęp"21. Również biskupi polscy wyrazili solidarność z papieżem, orzekając, że celem norm Motu Proprio jest „zachowanie bogatego dziedzictwa

${ }^{17}$ Por. Konferencja EPISKopatu Polski, Głos biskupów polskich w związku
$z$ opublikowaniem przez Benedykta XVI Motu proprio „Summorum Pontificum”
(7 VII 2007), Akta Konferencji Episkopatu Polski 13(2007), s. 65; K. LehmanN,
Wyjaśnienie do Motu Proprio „Summorum Pontificum” (7 VII 2007), tł. z niem. S. Cichy, Anamnesis 13(2007) nr 4, s. 45-46.

${ }^{18}$ Por. Konferencja Episkopatu Polski, Wskazania Konferencji Episkopatu dla diecezji polskich dotyczące sprawowania Mszy św. według ogłoszonego przez papieża Benedykta XVI listu apostolskiego w formie motu proprio Summorum Pontificum (3 X 2007), Akta Konferencji Episkopatu Polski 13(2007), s. 67-68.

${ }^{19}$ Por. Konferenz des Deutschen Episkopats, Apostolisches Schreiben Motu proprio Summorum Pontificum. Leitlinien für die deutschen Diözesen (1 X 2007), http://www.dbk.de/fileadmin/redaktion/presse_import/2007-068_1-leitlinien_ summorum_pontificum.pdf [dostęp: 15 XII 2017]; tekst polski: KonfERENCJA EPIskopatu Niemiec, List Apostolski Motu Proprio Summorum Pontificum. Wskazania dla diecezji niemieckich, Anamnesis 14(2008) nr 52, s. 48-49.

${ }^{20}$ Por. Konferencja Episkopatu SzwajCari, List Apostolski Motu Proprio Summorum Pontificum. Wskazania biskupów szwajcarskich (1 X 2007), Anamnesis 14(2008) nr 52, s. 50-51.

${ }^{21}$ Por. K. Lehmann, Wyjaśnienie do Motu Proprio..., s. 45. 
liturgicznego i zwrócenie uwagi na ciągłość kultu Bożego w Kościele. Mają one także ułatwić odnalezienie utraconej więzi jedności środowiskom, które z powodu przywiązania do liturgii przedsoborowej oddaliły się od pełnej jedności z Kościołem”22.

\section{Dwie formy rytu rzymskiego i kwestia zakazu Mszału Jana XXIII}

Benedykt XVI publikując Motu Proprio Summorum Pontificum, a tym samym dopuszczając do szerokiego użytku Mszał Piusa V, określił go jako formę nadzwyczajna rytu rzymskiego. Mszał zaś Pawła VI został określony forma zwyczajna rytu rzymskiego oraz zwyczajnym wyrażeniem lex orandi Kościoła katolickiego obrządku łacińskiego (SP $1^{23}$, UE $6^{24}$ ). Dlatego papież w Liście do Biskupów z okazji publikacji Motu Proprio jasno podkreślił, iż niewłaściwe jest określanie tych form liturgii jako dwóch różnych rytów ${ }^{25}$. Zapewniał również w tym Liście, że „nie ma żadnej sprzeczności między jednym a drugim wydaniem Missale Romanum. W historii liturgii jest rozwój i postęp, ale bez żadnego rozłamu. To, co dla poprzednich

\footnotetext{
${ }^{22}$ Por. Konferencja Episkopatu Polski, Głos biskupów polskich..., s. 65.

${ }^{23}$ „Missale Romanum a Paulo VI promulgatum ordinaria expressio «Legis orandi» Ecclesiae catholicae ritus Latini est. Missale autem Romanum a S. Pio V promulgatum et a beato Ioanne XXIII denuo editum habeatur uti extraordinaria expressio eiusdem «Legis orandi» Ecclesiae et ob venerabilem et antiquum eius usum debito gaudeat honore".

${ }^{24}$ „I testi del Messale Romano di Papa Paolo VI e di quello risalente all'ultima edizione di Papa Giovanni XXIII, sono due forme della Liturgia Romana, definite rispettivamente ordinaria e extraordinaria: si tratta di due usi dell'unico Rito Romano, che si pongono l'uno accanto all'altro. L'una e l'altra forma sono espressione della stessa lex orandi della Chiesa. Per il suo uso venerabile e antico, la forma extraordinaria deve essere conservata con il debito onore".

25 „Non è appropriato parlare di queste due stesure del Messale Romano come se fossero due Riti. Si tratta, piuttosto, di un uso duplice dell'unico e medesimo Rito". Por. K. PonosŁo, Dwie formy, jeden ryt. Refleksja nad wzajemna relacja dwóch form rytu rzymskiego w świetle motu proprio „Summorum pontificum”, Anamnesis 14(2009) nr 3, s. 81-91.; M. AugÉ, Due «forme» per uno stesso rito?, Rivista Liturgica 96(2009), pp. 687-695.
} 
pokoleń było święte, również dla nas pozostaje święte i wielkie, i nie może być nagle całkowicie zabronione albo uznane za szkodliwe. Nas wszystkich buduje zachowywanie wartości, jakie wyrosły z wiary i z modlitwy Kościoła oraz przyznanie im słusznego miejsca” (por. UE 7) ${ }^{26}$. Także w Ogólnym Wprowadzeniu do Mszału Rzymskiego podkreślono wierność tradycji obu Mszałów ${ }^{27}$. W Liście do Biskupów z 2007 r. papież rozwiał również wątpliwości, iż wprowadzenie formy nadzwyczajnej doprowadzi do rozłamów w parafiach. Zapewnił, iż poprzez uwarunkowania prawne, jak i trudność w stosowaniu Mszału Jana XXIII m.in. poprzez użycie języka łacińskiego, forma zwyczajna pozostanie powszechnym sposobem sprawowania liturgii ${ }^{28}$.

${ }^{26}$ „Non c'è nessuna contraddizione tra l'una e l'altra edizione del Missale Romanum. Nella storia della Liturgia c'è crescita e progresso, ma nessuna rottura. Ciò che per le generazioni anteriori era sacro, anche per noi resta sacro e grande, e non può essere improvvisamente del tutto proibito o, addirittura, giudicato dannoso. Ci fa bene a tutti conservare le ricchezze che sono cresciute nella fede e nella preghiera della Chiesa, e di dar loro il giusto posto".

${ }^{27}$ Por. Ogólne Wprowadzenie do Mszału rzymskiego. Z trzeciego wydania Mszału Rzymskiego, Poznań 2006, nr 6. „Gdy Sobór Watykański II zarządził odnowę obrzędów Mszy świętej, polecił między innymi, by niektóre obrzędy przywrócono stosownie do pierwotnej tradycji Ojców Kościoła, czyli używając tego samego wyrażenia, co św. Pius V w Piśmie apostolskim zaczynającym się od słów Quo primum, którym w roku 1570 ogłoszony został Mszał Trydencki. Ta zgodność słów pozwala stwierdzić, jakim sposobem oba Mszały Rzymskie, chociaż dzielą je cztery wieki, zawierają jedną i tę samą tradycję. Jeśli zaś rozważymy wewnętrzne elementy tej tradycji, zrozumiemy, jak wspaniale drugi mszał udoskonala pierwszy”.

${ }^{28}$ „In secondo luogo, nelle discussioni sull'atteso Motu Proprio, venne espresso il timore che una più ampia possibilità dell'uso del Messale del 1962 avrebbe portato a disordini o addirittura a spaccature nelle comunità parrocchiali. Anche questo timore non mi sembra realmente fondato. L'uso del Messale antico presuppone una certa misura di formazione liturgica e un accesso alla lingua latina; sia l'una che l'altra non si trovano tanto di frequente. Già da questi presupposti concreti si vede chiaramente che il nuovo Messale rimarrà, certamente, la forma ordinaria del Rito Romano, non soltanto a causa della normativa giuridica, ma anche della reale situazione in cui si trovano le comunità di fedeli”. Por. także: K. Lehmann, Wyjaśnienie do motu proprio..., s. 46. „Celebracja parafialnych liturgii zasadniczo odbywa się nadal w zwyczajnej formie obrządku rzymskiego, a więc według odnowionych ksiąg liturgicznych”. 
Benedykt XVI stwierdził również, że Mszał Piusa V wydany przez Jana XXIII nie został nigdy zakazany $(\mathrm{SP} 1)^{29} \mathrm{i}$ w rezultacie był zawsze dozwolony $(\mathrm{LdB})^{30}$. Ta wypowiedź papieża przysparza wielu problemów interpretacyjnych, gdyż z wypowiedzi Pawła VI oraz z dokumentów dykasterii Stolicy Apostolskiej wynika, iż został on zniesiony. Już bowiem dn. 29 grudnia 1972 r. Sekretariat Stanu stwierdził, że status prawny i możliwość celebrowania tradycyjnej liturgii zostały rozwiązane w Konstytucji Apostolskiej Missale Romanum, wprowadzającej nowy Mszał ${ }^{31}$. O zniesieniu Mszału Jana XXIII świadczą również wydawane w drodze wyjątku zezwolenia na korzystanie z tego Mszału, które zostały omówione powyżej. Ponadto według kan. 20 KPK wydanie nowej edycji Mszału w 1970 r. jest uchyleniem poprzednich regulacji liturgicznych, jako uporządkowanie przez ustawę późniejszą w całości przedmiotu sprawy.

Kanoniści wysuwają więc kilka możliwości w interpretacji słów Benedykta XVI o braku zakazu Mszału Jana XXIII. Proponują optykę, iż sam Mszał nie został wprost zakazany, ale jego używanie zostało zakazane ${ }^{32}$. A także, iż użycie tego Mszału nie było zakazane jako takie, ale że nie było zakazane jako nadzwyczajna forma rytu

${ }^{29}$ „Proinde Missae Sacrificium, iuxta editionem typicam Missalis Romani a B. Ioanne XXIII anno 1962 promulgatam et numquam abrogatam, uti formam extraordinariam Liturgiae Ecclesiae, celebrare licet”.

${ }^{30}$ „Quanto all'uso del Messale del 1962, come forma extraordinaria della Liturgia della Messa, vorrei attirare l'attenzione sul fatto che questo Messale non fu mai giuridicamente abrogato e, di conseguenza, in linea di principio, restò sempre permesso".

${ }^{31}$ Por. A. Bugnini, La riforma liturgica (1948-1975), Roma 1997, p. 299. „La Costituzione apostolica Missale Romanum e la sua portata giuridica sono chiarissime”; G. May, Die alte und die neue Messe. Die Rechtslage hinsichtlich des Ordo Missae, Sankt Augustin 1984, p. 49. Autor zakłada, że Konstytucja Apostolska Missale Romanum zawiera intencję papieża o zakazie tzw. Mszy Trydenckiej albo Mszy Piusa V. Ponadto stwierdzić należy, iż zakaz ten dotyczy rytu rzymskiego, a nie innych rytów zachodnich, które wycofane zostały poprzez promulgację nowych Mszałów tych rytów.

${ }^{32}$ Por. Ch.J. Glendinning, Summorum Pontificum..., pp. 237-238; J.M. Huels, Reconciling the Old with the New. Canonical Questions on Summorum Pontificum, 
rzymskiego. Było także nieprzerwanie w użyciu w niektórych wspólnotach kościelnych ${ }^{33}$. Wypowiedź Benedykta XVI jest, więc różnie interpretowana przez kanonistów ${ }^{34}$.

\section{Podstawowe regulacje prawne użycia nadzwyczajnej formy rytu rzymskiego}

Poprzez Motu Proprio Summorum Pontificum Benedykt XVI wprowadził szereg regulacji prawnych w stosowaniu ksiąg liturgicznych sprzed II Soboru Watykańskiego. Jeśli chodzi o normy dyscyplinarne związane z celebracją, stosuje się dyscyplinę kościelną zawartą w Kodeksie z 1983 r (UE 27) ${ }^{35}$. „Ponadto, na mocy swojego charakteru jako prawa specjalnego, Motu Proprio Summorum Pontificum w swoim własnym zakresie znosi wszystkie przepisy prawa, związane ze świętymi obrzędami, promulgowane po 1962 r. nie dające się zastosować do rubryk ksiąg liturgicznych obowiązujących w 1962 r." (UE 28) ${ }^{36}$.

The Jurist 68(2008), p. 94. „While the Missal itself was not explicitly abrogated, the freedom to use it was expressly abrogated".

${ }^{33}$ Por. G. Read, The Motu Proprio Summorum Pontificum, Canon Law Society of Great Britain and Ireland Newsletter 9(2007) nr 151, p. 14. Autor artykułu proponuje inny motyw stwierdzenia numquam abrogata: „I suspect that the point of including this phrase is to calm the fears of supporters of the Society of St. Pius $\mathrm{X}$ that legislation enacted by one Pope could easily be revoked by another. It will also enable them to claim that, at least on this point, they were right all along, and have been unjustly treated. Perhaps such a step is necessary to allow healing and reconciliation to take place, even if [it] does not guarantee that it will happen".

${ }^{34}$ Por. Ch.J. Glendinning, Was the 1962 Missale Romanum Abrogated? A Canonical Analysis in Light of Summorum Pontificum, Worship 85(2011) z. 1, pp. 31-37; N. LüDECKe, Canonical rimarks on the Motu Proprio Summorum Pontificum, tł. z niem. G.N. Deckant i G. von der Bank, Antiphon 13(2009) nr 3, pp. 199-205; CH. Binder, „Numquam abrogata”? kirchenrechtliche Reflexionen über das Motu Proprio „Summorum Pontificum” Papst Benedikts XVI, Würzburg Echter 2017.

${ }^{35}$ „Per quanto riguarda le norme disciplinari connesse alla celebrazione, si applica la disciplina ecclesiastica, contenuta nel vigente Codice di Diritto Canonico".

${ }^{36}$ „Inoltre, in forza del suo carattere di legge speciale, nell'ambito suo proprio, il Motu Proprio Summorum Pontificum, deroga a quei provvedimenti legislativi, 
Benedykt XVI zezwolił kapłanom obrząaku łacińskiego na używanie Mszału z 1962 r. bez udziału wiernych z jednym ministrantem (sine populo) bez potrzeby uzyskania zezwolenia ordynariusza lub Stolicy Apostolskiej (SP 237, UE 23). Do takich Mszy dołączyć się mogą wierni, którzy z własnej woli pragną w nich uczestniczyć (SP 4) ${ }^{38}$. Według Motu Proprio proboszczowie powinni chętnie przyjmować prośby obecnej na stałe (stabiliter existens) w parafii grupy wiernych (coetus fidelium), przywiązanych do liturgii przedsoborowej (UE 15) ${ }^{39}$. Dokonywać się to ma pod kierunkiem biskupa i w zgodzie ze zwykłą opieką duszpasterską w parafii (SP $5 \$ 1)^{40}$. Celebracje te mogą mieć miejsce codziennie, ale w niedzielę i święta odbyć się może jedna Msza

inerenti ai sacri Riti, emanati dal 1962 in poi ed incompatibili con le rubriche dei libri liturgici in vigore nel 1962".

${ }^{37}$ „In Missis sine populo celebratis, quilibet sacerdos catholicus ritus latini, sive saecularis sive religiosus, uti potest aut Missali Romano a beato Papa Ioanne XXIII anno 1962 edito, aut Missali Romano a Summo Pontifice Paulo VI anno 1970 promulgato, et quidem qualibet die, excepto Triduo Sacro. Ad talem celebrationem secundum unum alterumve Missale, sacerdos nulla eget licentia, nec Sedis Apostolicae nec Ordinarii sui".

${ }^{38}$ "Ad celebrationes sanctae Missae de quibus supra in art. 2 admitti possunt, servatis de iure servandis, etiam christifideles qui sua sponte id petunt". Por. N. LÜDECKE, Canonical rimarks..., pp. 205-209.

${ }^{39}$ „Un coetus fidelium potrà dirsi stabiliter exsistens ai sensi dell'art. $5 \$ 1$ del Motu Proprio Summorum Pontificum, quando è costituito da alcune persone di una determinata parrocchia che, anche dopo la pubblicazione del Motu Proprio, si siano unite in ragione della loro venerazione per la Liturgia nell'Usus Antiquior, le quali chiedono che questa sia celebrata nella chiesa parrocchiale o in un oratorio o cappella; tale coetus può essere anche costituito da persone che provengano da diverse parrocchie o Diocesi e che a tal fine si riuniscano in una determinata chiesa parrocchiale o in un oratorio o cappella". Por. N. LÜDECKE, Canonical rimarks..., pp. 209-214.

${ }^{40}$ „In paroeciis, ubi coetus fidelium traditioni liturgicae antecedenti adhaerentium stabiliter exsistit, parochus eorum petitiones ad celebrandam sanctam Missam iuxta ritum Missalis Romani anno 1962 editi, libenter suscipiat. Ipse videat ut harmonice concordetur bonum horum fidelium cum ordinaria paroeciae pastorali cura, sub Episcopi regimine ad normam canonis 392, discordiam vitando et totius Ecclesiae unitatem fovendo". 
w nadzwyczajnej formie rytu rzymskiego (SP $5 \$ 2)^{41}$. Proboszczowie winni również chętnie wyrazić zgodę na celebrację innych obrzędów, takich jak liturgia ślubu, celebracja pogrzebu czy z racji pielgrzymki (SP $5 \$ 3^{42}, 9 \$ 1^{43}$, UE 18). Natomiast w kościołach, które nie mają charakteru parafialnego albo konwentualnego, obowiązkiem rektora jest wyrazić zgodę na taką celebrację (SP $5 \$ 5)^{44}$. Prawodawca w Motu Proprio daje także możliwość sprawowania liturgii w forma extraordinaria w zgromadzeniach zakonnych i stowarzyszeniach życia apostolskiego. Jednakże celebracja częsta lub na stałe wymaga zgody wyższego przełożonego (SP 3) ${ }^{45}$.

Papież podkreślił również prawo wiernych do liturgii w nadzwyczajnej formie rytu rzymskiego. Stąd w Motu Proprio przypomniał o możliwości rekursu hierarchicznego. Jeśli wspomniana powyżej stała grupa wiernych (SP $5 \$ 1$ ) nie otrzymała zezwolenia od proboszcza, powinna skierować sprawę do biskupa diecezjalnego, który usilnie jest proszony, by spełnić ich prośbę. Jeżeli biskup nie jest w stanie tego uczynić, sprawa kierowana jest do Papieskiej Komisji Ecclesia

${ }^{41}$ „Celebratio secundum Missale B. Ioannis XXIII locum habere potest diebus ferialibus; dominicis autem et festis una etiam celebratio huiusmodi fieri potest”.

${ }^{42}$ „Fidelibus seu sacerdotibus id petentibus, parochus celebrationes, hac in forma extraordinaria, permittat etiam in adiunctis peculiaribus, uti sunt matrimonia, exsequiae aut celebrationes occasionales, verbi gratia peregrinationes”.

${ }^{43}$ „Parochus item, omnibus bene perpensis, licentiam concedere potest utendi rituali antiquiore in administrandis sacramentis Baptismatis, Matrimonii, Poenitentiae et Unctionis Infirmorum, bono animarum id suadente”.

${ }^{44}$ „In ecclesiis, quae non sunt nec paroeciales nec conventuales, Rectoris ecclesiae est concedere licentiam de qua supra”.

${ }^{45}$ „Si communitates Institutorum vitae consecratae atque Societatum vitae apostolicae iuris sive pontificii sive dioecesani quae in celebratione conventuali seu "communitatis" in oratoriis propriis celebrationem sanctae Missae iuxta editionem Missalis Romani anno 1962 promulgatam habere cupiunt, id eis licet. Si singula communitas aut totum Institutum vel Societas tales celebrationes saepe vel habitualiter vel permanenter perficere vult, res a Superioribus maioribus ad normam iuris et secundum leges et statuta particularia decernatur". 
Dei (SP 7) ${ }^{46}$. By zapewnić wiernym możliwość celebracji, biskup diecezjalny może również skorzystać z pomocy Papieskiej Komisji Ecclesia Dei (SP 8) ${ }^{47}$ lub też poprosić o pomoc kapłanów z instytutów lub stowarzyszeń życia apostolskiego podlegających tejże Komisji (UE 2). Ordynariusze powinni również zadbać o należyte przygotowanie kapłanów do sprawowania liturgii w forma extraordinaria, nie wykluczając również kształcenia seminarzystów (UE 21). „Zgodnie z Kodeksem Prawa Kanonicznego Biskupi diecezjalni mają czuwać nad zagwarantowaniem dobra wspólnego $\mathrm{w}$ dziedzinie liturgii i do czynienia tego w ten sposób, aby wszystko odbywało się godnie, w pokoju i ze spokojem, zawsze w zgodzie z intencją Biskupa Rzymu jasno wyrażoną przez Motu Proprio Summorum Pontificum. W przypadku sporu lub uzasadnionej wątpliwości w przedmiocie celebracji w formie nadzwyczajnej sąd jest zastrzeżony dla Komisji Papieskiej" (UE 13) ${ }^{48}$.

Poprzez wprowadzone regulacje ustawodawca wymaga odpowiednich umiejętności od kapłanów pragnących celebrować obrzędy liturgii w forma extraordinaria (SP $5 \$ 4$, UE 24). W Instrukcji Universae Ecclesiae doprecyzowano te wymogi: „a) Każdy kapłan katolicki, któremu nie jest to zabronione przez Prawo Kanoniczne, ma być uważany za zdatnego do celebrowania Mszy św. w formie nadzwyczajnej. b) Co się tyczy łaciny, konieczne jest, aby kapłan mający celebrować potrafił wypowiadać słowa poprawnie i rozumiał ich znaczenie. c) Jeśli chodzi o umiejętność odprawiania rytu, za zdatnych uważa się tych

${ }^{46}$ „Ubi aliquis coetus fidelium laicorum, de quo in art. $5 \$ 1$ petita a parocho non obtinuerit, de re certiorem faciat Episcopum dioecesanum. Episcopus enixe rogatur ut eorum optatum exaudiat. Si ille ad huiusmodi celebrationem providere non vult res ad Pontificiam Commissionem «Ecclesia Dei» referatur".

${ }^{47}$ „Episcopus, qui vult providere huiusmodi petitionibus christifidelium laicorum, sed ob varias causas impeditur, rem Pontificiae Commissioni «Ecclesia Dei» committere potest, quae ei consilium et auxilium dabit".

${ }^{48}$ „I Vescovi diocesani, secondo il Codice di Diritto Canonico, devono vigilare in materia liturgica per garantire il bene comune e perché tutto si svolga degnamente, in pace e serenità nella loro Diocesi, sempre in accordo con la mens del Romano Pontefice chiaramente espressa dal Motu Proprio Summorum Pontificum. In caso di controversia o di dubbio fondato circa la celebrazione nella forma extraordinaria, giudicherà la Pontificia Commissione Ecclesia Dei”. 
kapłanów, którzy z własnej woli przystępują do celebrowania według formy nadzwyczajnej, i tych, którzy czynili to w przeszłości" (UE 20) ${ }^{49}$.

Ponadto zostały uregulowane normy dotyczące używania Pontificale Romanum, Ceremoniale Episcoporum i Rituale Romanum (UE 35), a więc m.in. sprawowania sakramentu bierzmowania (SP 9 $\$ 2$, UE 29) czy udzielania święceń niższych i subdiakonatu (UE 30-31). Wprowadzono również regulacje dotyczące liturgii słowa w Mszy (SP 6, UE 26), używania Breviarium Romanum obowiązującego w 1962 r. (SP $9 \$ 3$, UE 32), celebracji Triduum Paschalnego (UE 33), a także stosowania przez zakony ich własnych rytów liturgicznych według ksiąg obowiązujących w 1962 r. (UE 34).

\section{Papieska Komisja Ecclesia Dei}

Dykasterią ściśle związaną z liturgią w nadzwyczajnej formie rytu rzymskiego jest Papieska Komisja Ecclesia Dei. Została ustanowiona przez Jana Pawła II Listem Apostolskim Ecclesia Dei adflicta z 2 lipca 1988 r. Jej zadaniem była troska o powrót do komunii kościelnej Bractwa Kapłańskiego Świętego Piusa X, a także troska o seminarzystów i byłych członków tegoż Bractwa, którzy pragnęli zachować pełną jedność z papieżem w świetle protokołu z 5 maja $1988 \mathrm{r}$. $(\mathrm{EDa} 6)^{50}$. Konkretne kompetencje tejże Komisji zostały określone poprzez reskrypt Quia peculiare munus udzielony przez Jana Pawła II

${ }^{49}$ „In merito alla questione di quali siano i requisiti necessari, affinché un sacerdote sia ritenuto «idoneo» a celebrare nella forma extraordinaria, si enuncia quanto segue: a) Ogni sacerdote che non sia impedito a norma del Diritto Canonico è da ritenersi idoneo alla celebrazione della Santa Messa nella forma extraordinaria. b) Per quanto riguarda l'uso della lingua latina, è necessaria una sua conoscenza basilare, che permetta di pronunciare le parole in modo corretto e di capirne il significato. c) Per quanto riguarda la conoscenza dello svolgimento del Rito, si presumono idonei i sacerdoti che si presentano spontaneamente a celebrare nella forma extraordinaria, e l'hanno usato precedentemente".

${ }^{50}$ Por. Protocol of 5 May 1988 between the Holy See and the Priestly Society of St. Pius X (5 V 1988), https://www.fssp.org/en/protoc5mai.htm [dostęp: 10 X 2017]. Był to protokół podpisany przez kard. Józefa Ratzingera jako prefekta Kongregacji Nauki Wiary i abpa Lefebvre. 
z dnia 18 października 1988 r. ${ }^{51}$ Do jej zadań należało m.in. wydawanie zezwoleń na używanie Mszału z 1962 r. czy kanoniczne erygowanie instytutów i stowarzyszeń życia apostolskiego dla liturgii przedsoborowej.

Wydając Motu Proprio Summorum Pontificum Benedykt XVI stanowi, że Komisja Ecclesia Dei oprócz uprawnień, które jej już przysługują, wykonuje władzę Stolicy Apostolskiej, czuwając nad zachowaniem i wprowadzeniem w życie przepisów papieskiego Motu Proprio (SP 12) ${ }^{52}$. W Instrukcji Universae Ecclesiae został doprecyzowany rodzaj tej władzy jako zwyczajna i zastępcza wobec Biskupa Rzymskiego w sprawach należących do jej kompetencji (UE 9) ${ }^{53}$. Tę władzę Komisja wykonuje na mocy uprawnień przyznanych przez Jana Pawła II, a potwierdzonych przez Benedykta XVI w Summorum Pontificum, a także „na mocy władzy wydawania decyzji w sprawie odwołań, słusznie do niej kierowanych jako do wyższej instancji, od ewentualnych rozporządzeń administracyjnych Ordynariusza, które wydają się sprzeczne z Motu Proprio" (UE $10 \$ 1$ ) ${ }^{54}$. Komisja ta wydaje osąd w sytuacjach wątpliwych w kwestii stosowania liturgii nadzwyczajnej formy rytu rzymskiego (UE 13). Do niej również jako do dykasterii Kurii Rzymskiej kieruje się rekurs hierarchiczny (SP 7-8). Sprawuje ona pieczę - po wcześniejszej aprobacie Kongregacji Kultu

${ }^{51}$ Por. Pontificia Commissio Ecclesia Dei, Rescriptum ex audientia Ss.mi quo Cardinali Praesidi Pontificiae Commissionis «Ecclesia Dei» speciales tribuuntur facultates, foras datur Quia peculiare munus (18 X 1988), AAS 82(1990), pp. 533-534.

52 „Eadem Commissio, ultra facultates quibus iam gaudet, auctoritatem Sanctae Sedis exercebit, vigilando de observantia et applicatione harum dispositionum”.

${ }^{53}$ „Summus Pontifex Pontificiae Commissioni Ecclesia Dei potestatem ordinariam vicariam dignatus est impertire in omnibus rebus intra eius competentiae fines, praesertim circa sedulam observantiam et vigilantiam in exsequendas dispositiones in Litteris Apostolicis Summorum Pontificum contentas (cf. art. 12)”.

54 „Praeter facultates olim a Joanne Paulo II concessas necnon a Benedicto XVI confirmatas (cf. Litterae Apostolicae Summorum pontificum, art.11 et art.12), Pontificia Commissio huiusmodi potestatem exercet etiam in decernendo de recursibus ei legitime commissis, prout hierarchicus Superior, adversus actum administrativum singularem a quolibet Ordinario emissum, qui Litteris Apostolicis videatur contrarius". 
Bożego i Dyscypliny Sakramentów - nad edycją tekstów liturgicznych dla liturgii przedsoborowej (UE 11, PB 64) ${ }^{55}$.

W 2009 r. Benedykt XVI Listem Apostolskim Motu Proprio Ecclesiae unitatem włączył Komisję w struktury Kongregacji Nauki Wiary $^{56}$. Spowodowane było to doktrynalną stroną dialogu Stolicy Apostolskiej z Bractwem Kapłańskim Św. Piusa X, po zdjęciu ekskomunik z biskupów tegoż Bractwa ${ }^{57}$. Przewodniczącym Komisji został więc prefekt Kongregacji Nauki Wiary, a Komisja miała składać się - jak dotąd - z sekretarza i urzędników ${ }^{58}$.

Poprzez instrukcję Universae Ecclesiae przypomniano także regulację prawną, obecną w kan. $1445 \$ 2 \mathrm{KPK}$, o możliwości zaskarżenia dekretów Papieskiej Komisji Ecclesia Dei, w których odnosi się ona do dekretów ordynariuszy w sprawie celebracji w forma extraordinaria: „Dekrety, za pomocą których Papieska Komisja decyduje w sprawach odwołań, mogą być zaskarżane ad normam iuris przed Najwyższym Trybunałem Sygnatury Apostolskiej” (UE $10 \$ 2$ ).

\section{Wspólnoty w pełnej jedności z Kościołem katolickim}

Spośród wspólnot celebrujących liturgię sprzed II Soboru Watykańskiego wyszczególnić możemy zróżnicowane struktury kościelne.

\footnotetext{
${ }^{55}$ Por. S.T. Doyle, The Pontifical Commission Ecclesia Dei. Purpose and Competence, The Jurist 73(2013) nr 1, pp. 132-142.

${ }^{56}$ Por. Benedictus XVI, Epistula Apostolica Ecclesiae unitatem Motu Proprio data (2 VII 2009), AAS 101(2009), pp. 710-711; tekst polski: BENEDYKT XVI, List Apostolski Motu Proprio Ecclesiae unitatem, Anamnesis 15(2009) nr 4, s. 5-6.

${ }^{57}$ Por. Tenże, Littera Apostolica. Ad Episcopos Ecclesiae Catholicae (10 III 2009), AAS 101(2009), pp. 270-276; tekst polski: Benedy KT XVI, List Ojca Świętego do biskupów w sprawie zniesienia ekskomuniki z czterech biskupów konsekrowanych przez abpa Lefebvre'a, Anamnesis 14(2009) nr 3, s. 11-14.

${ }^{58}$ Por. Tenże, Epistula Apostolica Ecclesiae unitatem, nr 6. „Itaque Pontificia Commissio Ecclesia Dei ita constituitur: a) Commissionis Praeses Praefectus est Congregationis pro Doctrina Fidei. b) Commissio proprium habet ordinem, Secretarium et Officiales complectentem. c) Praesidis est, Secretario iuvante, praecipuos eventus quaestionesque doctrinalis indolis studio discretionique committere postulationum ordinariarum Congregationis pro Doctrina Fidei, itemque superiori Summi Pontificis i udicio conclusiones concredere".
} 
Są to m.in. stowarzyszenia życia apostolskiego i instytuty życia konsekrowanego, których jest kilkadziesiąt ${ }^{59}$. Wspólnoty te podlegają $\mathrm{Pa}$ pieskiej Komisji Ecclesia Dei. Do działających w Polsce należą Bractwo Kapłańskie Świętego Piotra (FSSP $)^{60}$ oraz Instytut Dobrego Pasterza $(\mathrm{IBP})^{61}$. Swoje funkcjonowanie opierają na zatwierdzonych statutach albo Konstytucjach ${ }^{62}$. Istnieją również instytuty i stowarzyszenia nie podlegające wprost Komisji Ecclesia Dei, ale regularnie celebrujące liturgię w nadzwyczajnej formie rytu rzymskiego ${ }^{63}$.

Kolejną strukturą godną uwagi jest Administratura Apostolska św. Jana Marii Vianneya w Campos w Brazylii. Została ustanowiona Dekretem Animarum bonum Kongregacji ds. Biskupów w 2002 r. ${ }^{64}$

${ }^{59}$ Por. G. Śniadoch, Msza Święta Trydencka. Mity i prawda. Apologetyka starej Mszy dla początkujących, Ząbki 2014, s. 415-421. Autor umieścił tam listę tych wspólnot. Do męskich należą m.in.: Bractwo Kapłańskie Świętego Piotra, Instytut Dobrego Pasterza, Benedyktyni Niepokalanej, Benedyktyni Wieczystej Adoracji, Instytut Świętego Filipa Neri, Instytut Chrystusa Króla Najwyższego Kapłana, Bractwo św. Wincentego Ferrariusza, Kanonicy Regularni Matki Bożej, Kanonicy Regularni Matki Bożej, Tradycyjni Benedyktyni - Opactwo św. Marii Magdaleny w Le Barroux, Tradycyjni Trapiści - Opactwo w Marienwald. Wspólnoty żeńskie to np. Tradycyjne Benedyktynki - Opactwo Naszej Pani Wniebowziętej z Le Barroux, Kanoniczki Matki Bożej, Siostry Przenajświętszej Krwi z Schellenberg, Oblatki Maryi Królowej Apostołów, Karmelitanki z Karmelu Jezusa, Maryi i Józefa z Valparaiso, Dominikanki Ducha Świętego - Instytut Świętego Dominika z Baffe, Instytut Służek Królowej Apostołów, Siostry Eremitki Świętego Brunona z Kwerfurtu.

${ }^{60}$ Por. http://www.fssp.pl [dostęp: 5 VI 2017].

${ }^{61}$ Por. http://instytutdobregopasterza.pl [dostęp: 5 VI 2017].

${ }^{62}$ Por. np. Constitutions of the Priestly Fraternity of Saint Peter approved by the Holy See (29 VI 2003), Fribourg 2013, mps.

${ }^{63}$ Należą do nich np. Bractwo Chrystusa Kapłana, Franciszkanie Niepokalanej, Franciszkanki Niepokalanej, Misjonarze Jezusa, „Schola Veritatis”, Dominikanki Konwentualne, Marianki z Santa Rosa.

${ }^{64}$ Por. Congregatio pro Episcopis, Decretum de Administratione Apostolica personali „Sancti Ioannis Mariae Vianney” condenda Animarum bonum (18 I 2002), AAS 94(2002), pp. 305-308; tekst polski: KongregaCja DS. BISKupów, Dekret o ustanowieniu personalnej Administratury Apostolskiej Świętego Jana Marii Vianneya, Christianitas 21-22(2005), tł. P. Milcarek, s. 135-138. 
Dekret ten reguluje zasadnicze normy prawne działalności tej administratury. Jest to jedyna administratura apostolska o charakterze personalnym w Kościele katolickim, a powstała z Bractwa Kapłańskiego Świętego Jana Marii Vianneya założonego przez bpa Antônio de Castro-Mayera ${ }^{65}$. Administratura posiada własny statut, seminarium duchowne, parafie personalne, natomiast na jej czele stoi administrator apostolski personalny. Może on erygować instytuty życia konsekrowanego i stowarzyszenia życia apostolskiego oraz własne trybunały. Określona została również specyficzna korelacja administratury do diecezji Campos ${ }^{66}$.

Prócz Administratury personalnej w Campos, instytutów i stowarzyszeń życia apostolskiego, istnieją również struktury w Kościołach partykularnych, czyli głównie w diecezjach. Są nimi duszpasterstwa posiadające statuty nadane przez ordynariusza miejsca. W Polsce obecnie statut posiada kilka diecezjalnych duszpasterstw tradycji liturgicznej erygowanych dekretem biskupa diecezjalnego m.in. w Archidiecezji Warszawskiej ${ }^{67}$ czy Wrocławskiej ${ }^{68}$. Biskupi diecezjalni

${ }^{65}$ Por. Joannes Paulus II, Littera Ecclesiae unitas (25 XII 2001), Communicationes 34(2002), pp. 11-12; Lettera 15 agosto 2001 del Vescovo e dei sacerdoti di Campos al Santo Padre, Il Diritto Ecclesiastico 94(2003), pp. 369-372; Oświadczenie personalnej Administratury Apostolskiej „Św. Jana Marii Vianneya”, Christianitas 21-22(2005), s. 139-144.

${ }^{66}$ Por. J. Bednarz, Administratura apostolska personalna „Świętego Jana Marii Vianneya”, Annales Canonici 1(2005), s. 146-174; Tenże, La Administración Apostólica como figura especial en la organización eclesiástica, http://dadun.unav.edu/ bitstream/10171/6773/1/22_JERZY_PIOTR.pdf [dostęp: 28 X 2017]. Jest to rozdział pracy doktorskiej, którą Jerzy P. Bednarz obronił w 2004 r. na Uniwersytecie Navarry w Pampelunie.

${ }^{67}$ Por. K. Nycz, Statut Duszpasterstwa Wiernych Tradycji Łacińskiej w Archidiecezji Warszawskiej korzystajacych z nadzwyczajnej formy Rytu Rzymskiego z siedziba przy kościele parafialnym pw. Klemensa Hofbauera Warszawa, ul. Karolkowa (6 VI 2011), http://www.mszatrydencka.waw.pl/index.php/duszpasterstwo [dostęp: 2 VI 2017].

${ }^{68}$ Por. J. Kupny, Statut Duszpasterstwa Wiernych Tradycji Łacińskiej w Archidiecezji Wrocławskiej z siedziba we Wrocławiu przy Parafii rzymskokatolickiej pw. Najświętszej Maryi Panny na Piasku (9 XII 2013), http://www.tradycja.archidiecezja. wroc.pl/statut [dostęp: 2 VI 2017]. 
erygowali również parafie personalne dla nadzwyczajnej formy rytu rzymskiego, mianując dla nich kapelanów (SP 10) ${ }^{69}$. Przykładem takiej parafii jest parafia personalna pw. Naszej Pani z Lourdes w Kentu$\mathrm{cky}^{70}$. Parafie personalne prowadzone są także przez Administraturę personalną w Campos, jak to już zostało nadmienione, a także przez stowarzyszenia życia apostolskiego ${ }^{71}$.

Nie brakuje również stowarzyszeń świeckich i kleryckich skupionych wokół celebracji tej liturgii, jak np. Stowarzyszenie Una Voce ${ }^{72}$ czy Stowarzyszenie Kapłańskie Summorum Pontificum ${ }^{73}$.

\section{Wspólnoty bez pełnej jedności z Kościołem katolickim}

Wspólnoty nie utrzymujące pełnej jedności ze Stolicą Apostolską, które związane są ściśle z celebracją liturgii według ksiąg sprzed II Soboru Watykańskiego możemy podzielić na dwie grupy związane $\mathrm{z}$ abp. Lefebvre oraz związane $\mathrm{z}$ teoriami sedewakantystycznymi i sedeprywacjonistycznymi.

W posoborową sytuację, mocno wpisuje się Bractwo Kapłańskie Świętego Piusa X, erygowane 1 listopada 1970 r. jako stowarzyszenie wiernych, któremu przewodniczył abp Lefebvre ${ }^{74}$. Odrzucając

69 „Fas est Ordinario loci, si opportunum iudicaverit, paroeciam personalem ad normam canonis 518 pro celebrationibus iuxta formam antiquiorem ritus romani erigere aut rectorem vel cappellanum nominare, servatis de iure servandis".

${ }^{70}$ Por. R.J. Foys, Decree of Erecting the Personal Quasi-Parish of Our Lady of Lourdes (7 X 2016), https://drive.google.com/file/d/0B4_xHxezC4PzbVg5eldCdWhVNnc/ view [dostęp: $18 \mathrm{X}$ 2017].

${ }^{71}$ Por. J.F. Donoghue, Decree of Establishing St. Francis de Sales Catholic Church (27 I 1999), https://stfrancisdesalesparish.files.wordpress.com/2014/07/parish-decree.jpg [dostęp: 17 I 2018]. Jest to parafia prowadzona przez Bractwo Kapłańskie Świętego Piotra.

${ }^{72}$ Por. http://www.fiuv.org [dostęp: 2 VI 2017].

${ }^{73}$ Por. http://www.giovanietradizione.org/amicizia [dostęp: 2 VI 2017].

${ }^{74}$ Por. http://fsspx.org/fr; http://www.piusx.org.pl [dostęp: 3 VI 2017]; Aby Kościót trwał. Arcybiskup Marcel Lefebvre w obronie Kościoła i papiestwa. Dokumenty z lat 1971-1990, Warszawa 2011. Wspomnieć też należy, iż istnieje kilka wspólnot związanych z Bractwem Kapłańskim Św. Piusa X. Są to m.in. Bractwo Przemienienia Pańskiego, Dominikanie Tradycji w z Avrillé, Kapucyni Tradycyjnej Obserwancji 
niektóre postanowienia II Soboru Watykańskiego, Bractwo pozostało przy liturgii według Mszału Piusa V. Popadło również w konflikt ze Stolicą Apostolską, z którą obecnie prowadzi dialog w celu uzyskania statusu kanonicznego. Benedykt XVI wspomnianym już Listem Apostolskim Motu Proprio Ecclesiae unitatem z 2009 r. zniósł ekskomuniki nałożone na czterech biskupów wyświęconych bez mandatu Stolicy Apostolskiej ${ }^{75}$. Papież Franciszek udzielił kapłanom Bractwa upoważnienia do ważnego rozgrzeszania w sakramencie pokuty ze względu na Jubileusz Miłosierdzia w 2015 r. ${ }^{76}$, które następnie przedłużył na czas nieokreślony ${ }^{77}$. Ponadto w 2016 r. pojawiły się informacje, że Kongregacja Nauki Wiary w 2016 r. potwierdziła władzę przewodniczącego Bractwa, bpa Bernarda Fellay'a, do kanonicznego sądzenia kapłanów Bractwa oraz dała możliwość udzielania święceń bez pytania o zgodę ordynariusza miejsca ${ }^{78}$. Dekretem Papieskiej Komisji Ecclesia Dei została również uregulowana kwestia braku formy kanonicznej, której nie mają kapłani Bractwa przy asystowaniu zawieranym małżeństwom ${ }^{79}$. Wynikiem dialogu prowadzonego ze Stolicą

oraz Opactwo Benedyktyńskie Krzyża Świętego w Nova Friburgo. Warto podkreślić, że 26 czerwca 2008 r. redemptoryści z Papa Stronsay należący do ruchu abp. Lefebvre powrócili do jedności ze Stolicą Apostolską.

${ }^{75}$ Por. Benedy kt XVI, Ecclesiae unitatem, nr 4; Benedictus XVI, Littera Apostolica ad Episcopos Ecclesiae Catholicae (10 III 2009), AAS 101(2009), pp. 270-276; tekst polski: BENEDYKT XVI, List Ojca Świętego do biskupów w sprawie zniesienia ekskomuniki z czterech biskupów konsekrowanych przez abpa Lefebvre'a, Anamnesis 14(2009) nr 3, s. 11-14.

${ }^{76}$ Por. Franciscus, Littera. Iubilaeo Extraordinario Misericordiae Adveniente, ad Venerabilem Fratrem Salvatorem Fisichella, Praesidium Pontificii Consilii de Nova Evangelizatione Promovenda (1 IX 2015), AAS 107(2015), p. 976; tekst polski: FrANCISZEK, List przed Jubileuszem Miłosierdzia, http://niedziela.pl/artykul/19456/ Franciszek-list-przed-Jubileuszem [dostęp: 6 XII 2017].

${ }^{77}$ Por. Tenże, Littera Apostolica Misericordia et misera de Iubilaeo Extraordinario Misericordiae concludendo (20 XI 2016), AAS 108(2016), p. 1320; tekst polski: Franciszek, List Apostolski Misericordia et misera, Kraków 2016, nr 12.

${ }^{78}$ Por. https://adelantelafe.com/vaticano-habria-autorizado-las-ordenaciones-la-fsspx-este-ano-monsgalarreta [dostęp: 5 VI 2017].

${ }^{79}$ Por. Pontificia Commissione ECCLesia Dei, Lettera ai Presuli delle Conferenze Episcopali interessate circa la licenza per la Celebrazione di Matrimoni dei Fedeli 
Apostolską może być przekształcenie Bractwa w drugą prałaturę personalną. Wspomnieć można także o wspólnotach przywiązanych do bpa Williamsona, który odłączył się od Bractwa Kapłańskiego Świętego Piusa X.

Rzeczywistość pozakościelną stanowią natomiast wspólnoty o poglądach sedewakantystycznych i sedeprywacjonistycznych ${ }^{80}$. Są to nurty powstałe na kanwie zmian, które dokonały się w Kościele po II Soborze Watykańskim ${ }^{81}$. Zwolennicy sedewakantyzmu, opierając się na fałszywym rozumieniu dogmatu o nieomylności papieża, uważają, że po pontyfikacie Piusa XII Stolica Apostolska jest w stanie wakatu, gdyż wszyscy nowo wybrani Biskupi Rzymu nie są ważnie wybranymi papieżami. W swoich opracowaniach próbują wykazać, że ci papieże trwają w jawnej herezji, stąd jako ekskomunikowani, a nawet jako apostaci nie mogą być prawdziwymi papieżami ${ }^{82}$. Natomiast teoria sedeprywacjonistyczna, której twórcą był Guérard des Lauriers, zakłada, że z powodu herezji modernizmu papieże i obecni biskupi spoza tego nurtu utracili władzę jurysdykcyjnąa ${ }^{83}$.

della Fraternità San Pio X (4 IV 2017), http://press.vatican.va/content/salastampa/ it/bollettino/pubblico/2017/04/04/ 0218/00485. html [dostęp: 2 VI 2017].

${ }^{80}$ Wspólnotami schizmatyckimi ściśle związanymi z sedewakantyzmem są np. Kościół Palmariański, Trydencki Kościół Katolicki, Bractwo Niepokalanej Maryi Panny, Bractwo Świętego Jana Apostoła i Bractwo Świętego Piusa V.

${ }^{81}$ Por. T. Niecikowski, Sedewakantyzm. Zarys historii i doktryny radykalnego skrzydła katolickiego ruchu tradycjonalistycznego, Nomos 30-31(2000), s. 101-121; P. PAWELEC, Sedewakantyzm: wybrane zagadnienia, Resovia Sacra 16(2009), s. 321-335.

${ }^{82}$ Por. Dimond M., Dimond P., La verdad de lo que le ocurrió a la Iglesia Católica después del Segundo Concilio Vaticano, t. 1-2, Fillmore. Jest to obszerna analiza sytuacji Kościoła katolickiego po II Soborze Watykańskim, oparta na poglądach sedewakantystycznych. Natomiast stroną internetową sedewakantystów w Polsce jest: http://www.ultramontes.pl. Zwolennicy tego nurtu powołują się na kan. 188 nr 4 Kodeksu Prawa Kanonicznego z 1917 r.

${ }^{83}$ Por. T. Niecikowski, Sedewakantyzm..., s. 118-119. 


\section{Zakończenie}

W niniejszym artykule ukazano od strony prawnej obszerność zagadnienia obrzędów liturgii w nadzwyczajnej formie rytu rzymskiego po II Soborze Watykańskim. Jako temat dotychczas nie podjęty w polskiej kanonistyce, może stać się podstawą do dalszych i bardziej wnikliwych artykułów czy monografii. Opracowania te skupić się mogą na normach prawnych obrzędów liturgii, jak również na analizie kanonicznej pozycji prawnej struktur kościelnych, które zostały utworzone dla nadzwyczajnej formy lub są z nią ściśle związane. Ponadto temat ten jest zagadnieniem stosunkowo nowym w Kościele łacińskim, a liturgia ta spotyka się z coraz większym zainteresowaniem wiernych Kościoła. W tych kręgach polskich katolików dostrzega się potrzebę stworzenia gruntownego i systematycznego opracowania strony prawnej celebracji liturgii, szczególnie w strukturach diecezji i parafii.

Wobec papieskiej decyzji wydania Motu Proprio Summorum Pontificum nie brakuje wciąż zróżnicowanych postaw wśród wiernych, zarówno duchownych jak i świeckich. Spotkać się można z przyjęciem tego dokumentu $\mathrm{z}$ wielkim entuzjazmem i nadzieją na ubogacenie życia Kościoła, ale także z głębokim sceptycyzmem i wyrażanymi obawami, co do skutków koegzystencji obu form rytu rzymskiego. Benedykt XVI ustosunkował się do tych obaw, co zostało ukazane $\mathrm{w}$ artykule, mimo to dyskusja w tej materii jest wciąż żywa. W rezultacie przedmiot tematu niniejszego opracowania stanowić będzie zapewne rzeczywistość dynamiczną z otwierającymi się perspektywami na przyszłość.

\section{An extraordinary form of the roman rite}

Benedict XVI, through his Motu Proprio Summorum Pontificum from 2007, introduced new regulations for the celebration of the liturgy before the Second Vatican Council. This liturgy was described as the extraordinary form of the roman rite. The Pontifical Commission Ecclesia Dei was also created, which is responsible for the introduction of papal guidelines. In the Church, we can also see the richness of communities that celebrate the 
liturgy in the extraordinary form of the roman rite. Among them there are communities that maintain full communion with the Catholic Church and those that do not. The article shows the depth of the issue raised, which should be the subject of further, more thorough research and studies.

SŁOWA KLUCzOWE: nadzwyczajna forma rytu rzymskiego; liturgia przedsoborowa; Summorum Pontificum; liturgia tradycyjna

KEYWORDS: an extraordinary form of the roman rite; pre-conciliar liturgy; Summorum Pontificum; traditional liturgy

\section{Nota o Autorze:}

Ks. Mgr Lic. Dawid Pietras - kapłan diecezji zielonogórsko-gorzowskiej; doktorant Wydziału Prawa Kanonicznego UKSW. 